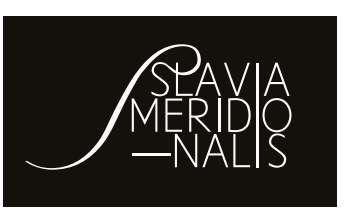

Citation:

Article No.: 1433

Pieniążek-Marković, K. (2017). Synekdocha literatury chorwackiej (Cvelferica, panonizam, pismo književnosti, znanosti i kulture, tomy 1-5, Cvelferija-Osijek 2015). Slavia Meridionalis, 17. https:// doi.org/10.11649/sm.1433

\title{
Krystyna Pieniążek-Marković
}

Uniwersytet im. Adama Mickiewicza w Poznaniu

\section{Synekdocha literatury chorwackiej (Cvelferica, panonizam, pismo književnosti, znanosti i kulture, tomy 1-5, Cvelferija-Osijek 2015)}

cvelferski korpus u književnopovijesnom i poetološko-stilskom smislu funkcionira kao sinegdoha ukupne hrvatske književnosti ${ }^{1}$

Pięciotomowe dzieło pod wspólną nazwą Cvelferica, panonizam, pismo književnosti, znanosti i kulture (Cvelferica, panonizm, tekst literatury, nauki $i$ kultury), to kompendium, na które składają się utwory zebrane oraz historyczno- i krytycznoliteracki ogląd twórczości powstałej na niewielkim obszarze zachodniego Sremu (chorw. Srijem), zwanym Cvelferija ${ }^{2}$, graniczącym z Serbią

1 Motto obecne w każdym tomie: „korpus cvelferski w sensie historycznoliterackim i poetologiczno-stylistycznym funkcjonuje jako synekdocha całej literatury chorwackiej". Wszystkie tłumaczenia z języka chorwackiego - K.P.M.

${ }^{2}$ Nazwa raczej nieoficjalna, stosowana jednak przez mieszkańców (potomków pograniczników z czasów walki z Imperium Osmańskim) i zawierająca geokulturowe odniesienia, utożsamiana z Assmanowską figurą wspomnień (pamięci) i miejscem pamięci (Pšihistal

This work was supported by the Polish Ministry of Science and Higher Education.

Competing interests: no competing interests have been declared.

Publisher: Institute of Slavic Studies, Polish Academy of Sciences.

This is an Open Access article distributed under the terms of the Creative Commons Attribution 3.0 PL License (creativecommons.org/licenses/by/3.0/pl/), which permits redistribution, commercial and non-commercial, provided that the article is properly cited. (c) The Author(s) 2017. 
(Wojwodiną) oraz Bośnią i Hercegowiną. Omawiane wieloautorskie dzieło współtworzą antologie tekstów (literatury ustnej, poezji, prozy, dramatu) poprzedzone krytycznymi omówieniami - wprowadzeniami. Określenie wieloautorskie odsyła zarówno do (wielu) autorów tekstów - są to chrestomatie skupiające literaturę oralną i pisaną niemal wszystkich twórców zamieszkujących przedmiotowe terytorium lub pochodzących z tego regionu - jak też (wielu) autorów i redaktorów opracowań. Pomysłodawcą projektu był Goran Rem, a realizacji idei wydania literackiego dziedzictwa wybranego obszaru wschodniej Chorwacji podjął się zespół badaczy z Zakładu Literatury Chorwackiej Wydziału Filozoficznego Uniwersytetu im. J. J. Strossmayera w Osijeku: Sanja Jukić, Ružica Pšihistal, Goran Rem, Ivan Trojan, przy ogromnej pomocy miejscowych działaczy kulturalnych i pracowników oświaty. Redaktorem tomów jest Ivan Rogić (poeta i socjolog). Rekonstrukcji historycznej, artystycznej, kulturowej przeszłości i teraźniejszości towarzyszy refleksja tożsamościowa o potrójnej identyfikacji - z Cvelferią, Szokadią i Chorwacją oraz o przynależności tej literatury do głównego toku rozwojowego chorwackiej kultury.

Bezpośrednim impulsem do opracowania summa Cvelferija stała się tragiczna powódź z 2014 roku i zwykły ludzki odruch humanisty pragnącego ocalić od zapomnienia, mającego świadomość, że jest świadkiem zanikania pewnego świata; humanisty - co istotne - zaangażowanego w badawcze obserwacje własnego lub bliskiego mu kulturowego terytorium. Proces „zanikania”, w drastyczny i najbardziej namacalny sposób uwidoczniony w czasie destrukcyjnej powodzi, rozpoczął się znacznie wcześniej i wywołany był uwarunkowaniami socjalnymi a także - jak sugeruje Franjo Nagulov - politycznymi ${ }^{3}$. Zjawisko pustoszejących wsi znamy także z polskiej rzeczywistości. W tekście wprowadzającym do tomu pierwszego, będącego zapowiedzią (i częściową konkretyzacją) całości ${ }^{4}$ pt. Priroda koja napada i kultura koja

\& Rem, 2016, s. 30). Terytorium Cvelferija obejmuje dziewięć wsi dawnego Pogranicza Wojskowego: Vrbanja, Soljani, Strošinci, Drenovci, Đurići, Račinovci, Gunja, Rajevo Selo i Posavski Podgajci. Termin Cvelferija wywodzi się z terminologii wojskowej języka niemieckiego (niem. $z w o ̈ l f$-dwanaście). W rejonie tym stacjonowała dwunasta kompania (chorw. satnija) siódmego regimentu (pukovnije) Pogranicza. Zamieszkiwany jest przez Szokców (Šokci).

3 „Gašenje Istoka” („wygaszanie Wschodu”) jest nieuniknioną konsekwencją centralistycznej polityki, uprawianej przez wszystkie rządy niepodległej Chorwacji - pisze Nagulov, omawiając projekt Cvelferica (Nagulov, 2016).

4 Zastosowano dość zaskakującą numerację serii, która nie rozpoczyna się od tomu pierwszego, lecz zerowego. Mimo że taka decyzja redakcyjna budzi moje wątpliwości, zamie- 
pismom brani (Atakująca przyroda i kultura broniąca pismem) Dario Grgić realizowany projekt utożsamia z procesem afirmacji podmiotu (mieszkańca) uprzedmiotowionego przez przyrodę, historię i instytucje kultury (dysponentów środków): ,jer je Instanca iziritiranom Prirodom uzvratno dokvačena, Poviješću zapuštena te Kulturom niskobudžetna” (Grgić, 2015, s. 15; ,jest bowiem Instancją w rewanżu / schwyconą przez zirytowaną Naturę, zaniedbaną przez Historię oraz niskobudżetową w Kulturze") ${ }^{5}$. Nie mam pewności, czy dobrze rozumiem autora, zakładając jednak, że tak, to zagrożenie ze strony natury oraz niezainteresowanie ze strony historii i kultury oznaczają słabe punkty, w których zgodnie z postulatami ponowoczesnych myślicieli należy widzieć miejsca produkcji hiperaktywnego tekstu (Grgić, 2015, s. 15). Tę hiperaktywność interpretuję jako wysoką produktywność, emanującą z terytorium szczególną energię twórczą, która została przełożona na konkret: pięć tomów literatury ludowej i popularnej, prozy fikcyjnej i autobiograficznej, poezji, dramatu, eseju, publicystyki.

Badania zespołu z Osijeku wpisują się ściśle w nurt geopoetyki i regiopoetyki, glokalności, geografii kulturowej czy szeroko rozumianych badań przestrzennych. Owocem „spacjalnego zwrotu kulturowego” kroatystów z Uniwersytetu im. J. J. Strossmayera, zapoczątkowanego w latach dziewięćdziesiątych XX wieku, są m.in. takie pozycje jak: Književni Osijek (Literacki Osijek), oprac. Stanislava Marijanovicia, Osijek 1996 (Marijanović, 1996); Slavonsko ratno pismo (Slawońskie piśmiennictwo wojenne) Gorana Rema, Osijek-Slavonski Brod-Vinkovci 1997 (Rem, 1997); Osječka čitanka. Sretne ulice (Osjeczka czytanka. Szczęśliwe ulice) Heleny Sablić Tomić i Gorana Rema, Osijek 2001 (Sablić Tomić \& Rem, 2001); Slavonski tekst hrvatske književnosti (Slawoński tekst literatury chorwackiej) Heleny Sablić Tomić i Gorana Rema, Zagreb 2003 (Sablić Tomić \& Rem, 2003); Vinkovačka književna povjesnica (Vinkovaczkie dzieje literackie) Ružicy Pšihistal

rzałam pozostać jej wierna w niniejszym omówieniu, jednak katalogi biblioteczne nadają poszczególnym zeszytom numerację rozpoczynającą się od jedynki, dlatego wybieram ten wariant zgodny z bibliograficzną normą. Zatem chorw. svezak 0 traktuję jako tom 1 itd.

${ }^{5}$ Cytowany tekst wskazuje na ważne kwestie związane $\mathrm{z}$ narodzinami projektu a wynikające z przyczyn obiektywnych, sam jednak - jak wymienione czynniki - irytuje stylem wypowiedzi balansującym na granicy pseudonaukowości, potoczności i niezrozumienia. Zgodnie z tą strategią narracyjną omawiany tom to „Rukopis urgentne kulturne intervencije [...]. Piše se, taj rukopis, kao interventno aktualno pisanje” (Grgić, 2015, s. 15) itd. („Rękopis naglącej interwencji kulturowej [...]. Pisze się, ten rękopis, jako interwencyjne aktualne pisanie"). 
i Gorana Rema, Vinkovci 2009 (Pšihistal \& Rem, 2009) ${ }^{6}$. Natomiast omawiane tomy Cvelfericy stanowią - w moim odczuciu - bezpośrednią kontynuację dwutomowej pracy Gorana Rema i Sanji Jukić Panonizam hrvatskoga pjesništva I: Studij Slava Panonije i Panonizam hrvatskoga pjesništva II. Od Janusa Pannoniusa do Satana Panonskog: interpretacije poetskih tekstova (Panonizm poezji chorwackiej I: Studium Sława Panonii oraz Panonizm poezji chorwackiej II. Od Janusa Pannoniusa do Satana Panonskiego: interpretacje tekstów petyckich), Osijek 2012, wyd. drugie 2013, wyd. trzecie 2014; Rem \& Jukić, 2014a, $2014 b^{7}$. Oba szeroko zakrojone projekty badawcze (panoński i cvelferski), wpisujące się w przestrzenne nurty badań, odsłaniają głębokie zależności „pisma” i egzystencji. Analiza panońskiej poezji wiedzie do konstatacji o dominującym w tekstach motywie wody (deszcze, powodzie, mgły, bagna i moczary), która determinuje tożsamość mieszkańców, natomiast Cvelferica powstaje jako rezultat rzeczywistego zderzenia z żywiołem.

${ }^{6}$ Oprócz badaczy związanych z Uniwersytetem w Osijeku, autorem pozycji poświęconej slawońskiemu regionalizmowi jest Vinko Brešić (2004). Anonimowy autor tekstu opublikowanego w „Głosie Slawonii” (11.06.2016) źródeł dzisiejszego slawońskiego „zwrotu regionalnego" upatruje w załamaniu Chorwackiej Wiosny (1971), które skutkowało rezygnacją z projektów narodowych i koncentracją na (bezpiecznym z punktu widzenia jugosłowiańskich władz i ideologii) zainteresowaniu stronami rodzinnymi (chorw. zavičaj). „Čuvena i slavna te tragična hrvatska sedamdesetiprva, a i Deklaracija o hrvatskome jeziku iz 1967., granice su tih procesa u kojima je svaki naš zavičaj, nakon manjih i većih žrtava, iznova tražio svoj identitet [...]. Zavičajnost se smatrala donekle bezopasnom. Zato su mudri slavonski zavičajnici za tim prostorom slobode i posegnuli” („Głośny i sławny oraz tragiczny chorwacki siedemdzisiątypierwszy, a także Deklaracja o języku chorwackim z 1967 roku stanowią granice tych procesów, w których każda nasza mała ojczyzna [strony rodzinne - KPM], po złożeniu mniejszych i większych ofiar, znów poszukiwała swej tożsamości [...]. Strony rodzinne wydawały się dość bezpieczne. Dlatego właśnie roztropni slawońscy piewcy sięgnęli do tej przestrzeni wolności.”). („Studija o panonizmu”, 2016). Ze względu na nieobecność metodologii badań przestrzennych w powstałych wówczas tekstach nie zaliczam ich do nurtu skoncentrowanego wokół namysłu nad poetyką przestrzeni czy geopetyką. Także w pracach powstałych w latach dziewięćdziesiątych XX wieku często nieostra jest linia demarkacyjna pomiędzy rekonstrukcją literackiego obrazu regionu, pozycjami o charakterze antologii/chrestomatii (np. Osječka čitanka. Sretne ulice), klasycznymi opracowaniami historycznoliterackimi a studiami/badaniami geoprzestrzennymi.

7 Panonizm rozumiany jest jako zespół geograficznych, historycznych i kulturowych cech charakterystycznych dla utworów powstałych na obszarze niegdysiejszego Morza Panońskiego - dzisiejszej Kotliny Panońskiej. Analizie poddano wiersze zawierające panońskie toponimy lub napisane przez autorów swą biografią związanych z Panonią. 
Lokalność w badaniach kroatystycznych nie jest zjawiskiem nowym. Funkcjonowanie ziem chorwackich $w$ ramach różnych organizmów państwowych, wielojęzyczność (sztokawski, czakawski, kajkawski, łaciński, cerkiewnosłowiański w redakcji chorwackiej, niemiecki, włoski, węgierski), trójpiśmienność (alfabety łaciński, głagolicki, cyrylicki), trójpodział kulturowo-cywilizacyjny Trójjedynego Królestwa (Chorwacja, Dalmacja, Slawonia) oraz charakterystyczne dla literatury przedromantycznej skupienie sztuki w konkretnych miejskich ośrodkach wymuszają badania literatury starszej, wpisujące się w strategie geografii kulturowej. Jednak - może poza literaturą odrodzeniową, projektowaną przez ideologów ruchu jako ponadregionalna - także nowsze ogniwa kultury chorwackiej odzwierciedlają regionalną różnorodność. Mimo to odnoszę nieodparte wrażenie, że żaden inny obszar, poza Slawonią i jej centrum w Osijeku, nie stał się przedmiotem tak intensywnego zainteresowania badaczy przestrzenności czy geopoetyki. Po rozpadzie Jugosławii Chorwaci nie byli zainteresowani dzieleniem, lecz jednoczeniem, dlatego dość niechętnie podchodzili do propozycji regionalnego oglądu własnej literatury, być może do odwrotu od regionalizmu przyczyniła się obawa przed utożsamieniem regionu z prowincją, być może ten "nurt integracyjny" jest także owocem silnie zakorzenionego w chorwackim imaginarium ideologemu przedmurza i progu Wschodu (islamskiego i prawosławnego), zdecydowanie dominującego nad ideologemem mostu, z którym można utożsamiać wąskie geograficzne pasmo Chorwacji - mostu między Wschodem a Zachodem oraz między Północą a Południem. Most zakłada obecność różnorodności i opozycji, natomiast przedmurze antycypuje przynależność całego obszaru do Zachodu, a w takiej perspektywie dopuszcza się jedynie podział na „regiony” Zachodu, czyli śródziemnomorze (południe kraju) i Europę Środkową (część północna) $^{8}$, a zatem zawsze „regiony centralne” - kolebkę europejskiej cywilizacji i środek Europy.

Analizując dyskurs poetycki z panońskiej perspektywy, Sanja Jukić i Goran Rem zwracali uwagę na formy dialogu tekstu regionalnego z głównym, ogólnonarodowym, nurtem poezji oraz dyskursami innych regionów, kładąc przy tym akcent na konieczność rewizji obowiązującego kanonu. Eksponowali również ponadnacjonalny charakter tej poezji i wynikającą stąd potrzebę glokalnych odczytań, wykraczania poza ramy literatury narodowej, pamię-

8 Ten podział literatury chorwackiej problematyzowany jest m.in. w artykułach Ivana Slamniga, Miry Muhoberac (1997), Pavla Pavličicia (1995) czy książce Sanjina Sorela Mediteranizam tijela (Sorel, 2003). 
tania zwłaszcza o okresie rozwoju kulturalnego w ramach jednego organizmu administracyjnego - niegdyś wspólnego państwa węgierskiego. Przypomnieli także o potrzebie włączenia do literatury chorwackiej twórczości pisarzy pozostających poza granicami państwa (Chorwatów z Węgier i Wojwodiny). Gest oddania głosu słabym, niesłyszanym i niedostrzeganym $\mathrm{z}$ centrum, peryferyjnym podmiotom - Kotliny Panońskiej czy Cvelferii - można łączyć z perspektywą badań postkolonialnych. W obu przypadkach, lecz szczególnie mocno w Cvelfericy, zwrot ku lokalności jest jednak nierozerwalnie związany ze zwrotem pamięciowym, a nawet dobitniej: próbą ocalenia z zagłady.

Pierwszy tom, którego autorami są Sanja Jukić, Ružica Pšihistal, Goran Rem i Ivan Trojan Cvelferica, panonizam, pismo književnosti i kulture, został pomyślany jako zwiastun całości. Opatrzony jest podtytułem Projekt (Projekt) i oznaczony jako tom 0 , zapowiedziano w nim publikację trzech kolejnych tomów: svezak I - tradicijsko pismo, svezak II - poezija, proza, dokument, svezak III - drama (tom I - tekst tradycji, tom II - poezja, proza, dokument, tom III - dramat). W trakcie realizacji projektu, zaplanowany jako jeden, tom poświęcony poezji, prozie i dokumentom, został podzielony na dwa: poezja $i$ metapismo oraz proza. W efekcie ukazało się zatem pięć tomów z numeracją rozpoczynającą się od zera: tom 1, S. Jukić, R. Pšihistal, G. Rem, I. Trojan Cvelferica, panonizam, pismo književnosti i kulture - projekt (Cvelferica, panonizm, tekst literatury i kultury - projekt), ss. 276 (svezak 0); tom 2, G. Rem, R. Pšihistal Cvelferica, žena se opremi u bilo, stavi žar i ajd - tradicijsko pismo (Cvelferica, kobieta ubierze się na biało, wstawi żar i idzie - tekst tradycji), ss. 390 (svezak 1); tom 3, S. Jukić, G. Rem Cvelferica, ispod sto jata vrana i izmedu sto njiva - poezija i metapismo (Cvelferica, pod stoma stadami wron i między stoma niwami), ss. 530 (svezak 2); tom 4, S. Jukić, G. Rem Cvelferica, ili jedan je Cvelfer tjedan-dva ranije sanjao - proza (Cvelferica, czyli pewien Cvelfer miat sen tydzień-dwa wcześniej - proza), ss. 566 (svezak 3); tom 5, G. Rem, I. Trojan Cvelferica ili su to trnci kakve samo neizvjesnost i iščekivanje mogu proizvesti - drama (Cvelferica lub sa to ciarki jakie moga wywołać tylko niepewność i wyczekiwanie - dramat), ss. 194 (svezak 4). W druku znajduje się tom 6 - podręcznik akademicki - S. Jukić, R. Pšihistal, G. Rem, I. Trojan Sinegdoha hrvatske književnosti, znanosti i kulture, cvelferski tekstualni korpus - studije, sveučilišni udžbenik (Synekdocha chorwackiej literatury, nauki i kultury, cvelferski korpus tekstów - studia, podręcznik uniwersytecki).

Poza autorami opracowań i wyborów, w realizacji projektu brały udział nauczycielki języka chorwackiego i bibliotekarki (Sanja Šušnjara, Katica 
Petrović, Marijana Džalo, Sanja Prister Pejakić, Anita Tufekčić) zatrudnione w miejscowych szkołach (w roli badaczek terenowych prowadzących rozmowy o teraźniejszości i przeszłości, spisujących wspomnienia i twórczość ustną oraz poszukujących wcześniejszych zapisów), grupa filmowa SKIG (Studija kreativnih ideja - Studium Kreatywnych Pomysłów) ze wsi Gunja, Stowarzyszenie Promocji Kultury Duhovno Hrašće (Duchowa Dąbrowa), obejmujące wszystkie dziewięć wsi, którego misją jest m.in. badanie historii regionu, działalność informacyjno-wydawnicza, organizacja wystaw itp.), Pjesnički susreti u Drenovcima (Poetyckie spotkania w Drenovcach - coroczne wydarzenie, na którym wręczane są nagrody za osiągnięcia w dziedzinie poezji), Općinska narodna knjižnica (Gminna Biblioteka Narodowa) Drenovci.

Pierwszy tom pięciotomowego dzieła otwiera wiersz Mary Švel (Schwell) Gamiršek Druga obala (Drugi brzeg), tekst Dario Grgicia Priroda koja napada i kultura koja pismom brani oraz dwie prace o charakterze wprowadzającym: I Uvod u citanje Cvelferice (Wprowadzenie do lektury Cvelfericy), będące rezultatem analizy problemowej i formalnej zamieszczonych w książce tekstów źródłowych, oraz II Nacrt korpusa (Zarys korpusu). Kompozycja pierwszego tomu (nazywanego także makietą metodologiczną i tekstową) ma sygnalizować strukturę całości. Poza artykułami wprowadzającymi zawiera on zatem trzy zasadnicze części (1. Tradicijsko pismo, 2. Poezija, proza, 3. Drama), a w każdej z nich każda wieś reprezentowana jest przez dwóch autorów (lub dwa zespoły w przypadku tekstów wieloautorskich). Publikację zamyka opis projektu (prawdopodobnie jest to przedruk przygotowanego wniosku grantowego). Jednym z kryteriów doboru tekstów do tomu-makiety był - wspomniany już - motyw wody. Ten klucz tematyczny, w intencji autorów, stanowi rodzaj dedykacji: „poświęcenia tragedii cvelferskiej [...], podczas gdy w finalnym wariancie trójksięgu jedynym kryterium będzie wartość estetyczna i kulturalna materiału" (Jukić, Pšihistal, Rem, \& Trojan, 2015, s. 20).

W rozdziale Tradicijsko pismo zostały zebrane źródła (głównie wytworzone, spisane w trakcie badań terenowych) literatury ustnej (chorw. usmena) i ludowej/ popularnej (chorw. pučka); podzielono je genologicznie: poezja, opowiadania i podania (mityczne i etiologiczne), opowieści o życiu - z zaskakującym zderzeniem narracji fikcyjnej i dokumentalnej, kolektywnej i indywidualnej (Jukić, Pšihistal, Rem, \& Trojan, 2015, s. 20). Twórczość popularną prezentuje utwór poetycki Sela Cvelferije niewidomego poety Đuki Galovicia, autora, który zilustrował chyba wszelkie odsłony wiejskiej egzystencji. Ze względu na swój rodzajowo i gatunkowo hybrydowy charakter. jako wyjątkowo intrygująca jawi się opublikowana 
twórczość ustna. W dominującą narrację prozatorską wplecione zostały utwory liryczne. Rozbudowane studium Uvod u citanje Cvelferice (Wprowadzenie do lektury Cvelfericy) informuje, jakie role odgrywają te liryczne partie większych prozatorskich całości (Jukić, Pšihistal, Rem, \& Trojan, 2015, s. 21-23).

Poezija, proza, dokument to rozdział, do którego z każdej wsi wybrano dwoje autorów uprawiających odmienne gatunki. Pokazanie bogactwa i różnorodności rodzajowej oraz gatunkowej tekstów badanego obszaru wskazane jest (Jukić, Pšihistal, Rem, \& Trojan, 2015, s. 25) jako cel nadrzędny rozdziału, dlatego występują w nim obok siebie zarówno autorzy znani i obecni w chorwackim kanonie literackim, jak i twórcy dotąd anonimowi. Zgromadzony korpus prozy zawiera więc formy dokumentalne, autobiograficzne, epistolografię, eseistykę i prozę fikcjonalną, natomiast korpus poezji - wiersze i prozę poetycką. Najstarszym z zamieszczonych w tej części twórców jest duchowny Stjepan Adžić (Rajevo Selo 1730-1789 Pecz) a najmłodszą pisarką - Magdalena Golubović (Đurići 1999).

Rozdział trzeci, Drama, najbardziej bezpośrednio dotyka kwestii wzajemnego przenikania doświadczeń egzystencjalnych i literatury. Do ilustracji dramatu (rodzaju literackiego) Cvelferii nie wybrano żadnego z utworów dramatycznych tego regionu, lecz dramat dokumentalny Potop napisany przez Ivana Trojana na podstawie zanotowanych reakcji na dramat (doświadczenie jednostki i zbiorowości) wsi zalanych przez powódź 17 maja 2014 roku. Teatr dokumentalny wykorzystuje źródła i wypowiedzi uczestników wydarzeń (świadków), kształtując obiektywny, lecz - jak przekonuje lektura wspomnianego utworu - niepozbawiony emocji obraz problemu. Potop zbudowany jest z fragmentów dzienników, notatek, prozy, eseju, wywiadów i sprawozdań pisarzy oraz pracowników ośrodków kultury, którzy bezpośrednio doświadczyli skutków tragedii: Sanji Šušnjary, Božicy Zoko, Gorana Pavlovicia, Ivicy Ćosić-Bukvina i Zvonimira Stjepanovicia.

W tomie drugim Cvelferica, žena se opremi u bilo, stavi žar i ajd - tradicijsko pismo zebrano i dokonano stratyfikacji tekstów literatury oralnej oraz popularnej/ludowej, zarówno spisywanych i nagrywanych od XIX wieku (autorem najstarszych zapisów, z 1875 roku, jest podróżujący po Slawonii ksiądz Mihovil Pavlinović), wcześniej publikowanych lub gromadzonych w bibliotekach, instytutach, pracowniach bądź zbiorach indywidualnych badaczy, jak i źródeł wytworzonych na potrzeby projektu - część z nich może stanowić materiał do badań nad antropologią codzienności oraz dziejów Chorwacji oglądanych z perspektywy peryferii, tzw. słabego, „niemego” (a właściwie niesłyszanego) podmiotu. W badaniach obecna jest zatem równocześnie per- 
spektywa zewnętrzna (zapisy dokonane przez przybyszów z innych regionów) oraz perspektywa wewnętrzna (źródła spisane przez samych mieszkańców). Zastosowano metodologię badań folklorystycznych i terenowych zgodną $\mathrm{z}$ dawnymi postulatami Antuna Radicia (Osnova za sabiranje i proučavanje narodnog života - Podstawy zbierania i badania życia ludu, 1897), czyli powierzono zapisywanie współuczestnikom badanego obszaru i kultury: „etnograficzny tekst piszą/zapisują uczestnicy kultury, ci, którzy naród doskonale znają i rozumieja, a nie podchodzą do materiału w poszukiwaniu ciekawostek i błahostek" (Pšihistal \& Rem, 2016, s. 33). Spisywanie twórczości ustnej przez kroatystki z cvelferskich szkół jest jednocześnie postępowaniem wpisującym się w najnowsze tendencje badań folklorystycznych, oznacza bowiem przyjęcie wewnętrznej perspektywy (etnografia własnego/bliskiego oraz autoetnografia) (Pšihistal \& Rem, 2016, s. 33-35).

Wykorzystując terminologię Radicia, materiał źródłowy z każdej wsi zgrupowano w trzech segmentach zatytułowanych Narodno srce (Serce narodu; materiał związany z obyczajami cyklu kalendarzowego/dorocznego, cyklu życiowego jednostki, cyklu prac a także z zabawą - zabawy panieńskie, kawalerskie i dziecięce), Narodna duša (Dusza narodu; głównie etiologiczne i demonologiczne podania oraz pieśni i przyśpiewki), Narodna pamet (Mądrość narodu; opowieści o życiu, przysłowia i powiedzenia). Uzasadnienie takiego podziału znajduje się w świetnie napisanym i podejmującym fundamentalne dla projektu kwestie studium Uvod u čitanje tradicijskoga pisma (Wprowadzenie do lektury tekstu tradycji), które z jednej strony jest mocno osadzone $\mathrm{w}$ dyskursie folklorystycznym, precyzyjne nakreśla zastosowaną metodologię badań oraz metodologię gromadzenia źródeł, z drugiej jednak strony - wykorzystując dyskurs pamięciowy - oferuje krótki rys historyczny regionu, w tym dotyczący nazwy i jej odzwierciedlenia w przedmiotach codziennego użytku',

9 „Dvanaest pruga, koje su nekada bile znak raspoznavanja pripadnika 12. kumpanije, postao je cvelferski znak upleten na špenzli / reklji / rekli / špenzletu, kratkom tamnoplavom kaputu od valjane vune, u obliku dvanaest raznobojnih valovitih vodoravnih pruga ili strika na rukavima i donjem obrubu kaputića, a sinovi jedinci, kicoši i bećari nosili su špenzleta do koljena sve do 30-ih godina 20. stoljeća” („Dwanaście pasków, które niegdyś były znakiem rozpoznawczym członków 12 kumpanii, stały się cvelferskim znakiem wplecionym na špenzli / reklji / rekli / špenzletu, krótkiej granatowej kurtce z wełny filcowej, w kształcie dwunastu różnokolorowych falistych poziomych pasków lub stryczków na rękawach i dolnym obrąbku kurtki, a synowie jedynacy, strojnisie i baciary nosili kurtki do kolan aż do lat 30. XX wieku", Pšihistal \& Rem, 2016, s. 31). 
a w odwołaniu do dyskursu tożsamościowego wyjaśnia zależności między cverlferskością a szokackością (określona jako chorwacki subetnos) oraz między szokackością a chorwackością.

Cvelferska chrestomatia poezji i utworów metatekstualnych to trzeci tom projektu Cvelferica, ispod sto jata vrana i izmedu sto njiva - poezija i metapismo, natomiast tom czwarty Cvelferica, ili jedan je Cvelfer tjedan-dva ranije sanjao - proza jest chrestomatią prozy. Koncepcja początkowa zakładała zebranie materiału poetyckiego i prozatorskiego w jednym tomie, jednak zgromadzone źródła okazały się zbyt liczne, wystarczające na kilka książek, zdecydowano więc o druku dwóch odrębnych pozycji. Podziału zapewne dokonano już na etapie łamania tekstów, o czym świadczy studium wprowadzające, które zostało „rozerwane” na fragmenty dotyczące poezji i prozy, ale jego część wstępna (także te informacje, które nie odnoszą się do danego tomu) powtarza się w obydwu pozycjach. Otrzymujemy zatem zapowiedzi, które realizowane są w innych tomach.

Twórczość poetycka obejmuje dorobek niemal stulecia, otwiera ją bowiem fascynująca, lecz nieznana szerszemu kręgowi odbiorców, powieść poetycka z 1928 roku Majka (Matka) Marii Tucaković-Grgić a zamykają wiersze powstałe równocześnie z omawianą publikacją. Poezję Cvelferii reprezentuje czternastu autorów, zarówno znanych wcześniej publiczności z wydanych tomików poetyckich lub innej aktywności artystycznej, jak i debiutujących właśnie na łamach Cvelfericy (Marija Tucaković-Grgić, Mara Švel-Gamiršek, Luka Pavlović, Marija Peakić-Mikuljan, Josip Šokčević-Mole, Andrija Matić, Marko Landekić-Udvin, Stjepan Jakševac, Mato Medvedović, Ante Kovač, Miroslav Mićanović, Krešimir Mićanović, Marinko Plazibat, Monika Vladisavljević, Sanja Šušnjara). Należą oni do różnych pokoleń i realizują różnorodne poetyki: socjalne zaangażowanie, model krugowaszki (lata pięćdziesiąte XX wieku), egzystencjalizm, neoegzystencjalizm, postmodernizm, intermedialność.

W studiach wprowadzających do obu tomów Poezija i metapismo - Cvelferijom nizvodno oraz Proza - Cvelferijom nizvodno ${ }^{10}$ skoncentrowano się na

${ }_{10}$ Nizvodno - czyli z biegiem rzeki - w takiej kolejności (zapowiedziano we wszystkich tomach) mieli być prezentowani twórcy: „idejna poveznica s ostalim knjigama Cvelferice i slijed je autora/tekstova unutar poglavlja ustrojen kao implicitna hidrografija Cvelferije. Drugim riječima, tekstna produkcija slaže se vodenim putem Save od zapada prema istoku nizom - Rajevo Selo, Posavski Podgajci, Gunja, Drenovci, Đurići, Vrbanja, Račinovci, Soljani, Strošinci” („ideowa nić łączącą z pozostałymi tomami Cvelfericy oraz kolejność autorów/tek- 
wnikliwej i osadzonej na podbudowie teoretycznej prezentacji indywidualnych poetyk, a nawet na analizie poszczególnych utworów ${ }^{11}$. Trochę szkoda, że zabrakło historycznoliterackiej syntezy próbującej prześledzić rys rozwojowy, ewentualne kontinuum tego dorobku. Ten niedosyt mogłoby zrekompensować dobre podsumowanie, rodzaj rekapitulacji kreującej obraz zbiorowy z rozproszonych indywidualnych portretów poetyckich i prozatorskich. Wydaje się, że autorom bardziej zależało jednak na wyeksponowaniu stylistycznej różnorodności (w której dostrzegają rodzaj matrycy dla całej literatury chorwackiej, Jukić \& Rem, 2015a, s. 50) niż pewnej regionalnej koherentności, spójności i odrębności. Różnorodność jest także eksponowana w przypadku tekstów zdefiniowanych jako metapismo, termin ten odsyła do prac o charakterze badawczym - historyczno- i teoretycznoliterackich, stylistycznych (Miroslava Mićanovicia, Very Erl, Sanji Šušnjary, Marinka Plazibata, Ante Kovača, Luki Pavlovicia i Marka Japundžicia), językoznawczych (Krešimira Mićanovicia, Katy Petrović), historycznych i geopolitycznych (Ivana Ćosicia-Bukvina), kulturologicznych (Ivo Azapovicia, Andriji Pekara, Tomislava Lunka, Vity Vidaković i Zlatka Filipovicia-Acina) oraz chemiczno-metalurgicznych (Franjo Hanamana) (Jukić \& Rem, 2015a, s. 44).

Zgromadzone teksty prozatorskie podzielono na prozę fikcjonalną (Mara Švel-Gamiršek, Ante Kovač, Miroslav Mićanović, Krešimir Mićanović, Marinko Plazibat) i niefikcjonalną: epistolografia (Stjepan Adžić, Josip Krunić, Marijana Janković), biografie (Stjepan Tomić), oświadczenia / słowa wstępne (izjava) (Andrija Matić, Marko Đidar, Jakša Šestić, Matej Janković, Ivan Ćosić-Bukvin), podróż (Milan Katičić, Ante Kovač), świadectwa (Tatjana Bertok-Zupković), przemowy/wystąpienia (Josip Purić-Karlin), publicystyka (Stjepan Tomić, Stjepan Bogutovac). Kilka utworów zostało przedrukowanych z tomu pierwszego, nie udało się bowiem dotrzeć do nowych produkcji ze wsi Đurići, a dla pełnego obrazu regionu autorzy wyboru nie chcieli zrezygnować z tekstowej

stów w ramach rozdziałów biegnie zgodnie z implicytną hydrografią Cvelferii. Innymi słowy, teksty ułożone są zgodnie z drogą wodną Sawy z zachodu na wschód, w kolejności: Rajevo Selo, Posavski Podgajci, Gunja, Drenovci, Đurići, Vrbanja, Račinovci, Soljani, Strošinci”, s. 16, tom 3 i s. 16 tom 4), tymczasem temu układowi pozostali wierni jedynie autorzy tomu 1 i 2 , antologie poezji i prozy otwierają teksty braci Mićanoviciów pochodzących z Gunji.

${ }^{11}$ Jeżeli dany pisarz prezentowany jest jako autor wielu rodzajów literackich, to biobibliograficzne informacje na jego temat rozproszone są w kilku tomach, a nawet kilku miejscach w tym samym tomie. Na przykład o Miroslavie Mićanoviciu czytamy: w studium wprowadzającym, w antologii poezji, antologii metapisma, antologii prozy. To chyba nadmiar. 
reprezentacji tej miejscowości. Ponownie wydano zatem autobiograficzne zapisy T. Bertok-Zupković, D. Golubovicia, M. Golubović i I. Baloga oraz epistolarną prozę M. Janković - w trosce, by w tomie prozatorskim nie zabrakło tego gatunku.

Tom piąty Cvelferica ili su to trnci kakve samo neizvjesnost $i$ iščekivanje mogu proizvesti - drama, w odróżnieniu od poprzednich, jest nie tylko antologią dzieł zebranych, ale także napisanych do tej właśnie chrestomatii, nosi najsilniejsze piętno autorskie (badacza) i piętno tragicznych przeżyć - dramatu egzystencjalnego. Poza dotąd niepublikowanym dramatem Mary Švel Gamiršek (zwanej szokacką Selmą Lagerlöf), pozostałe utwory stanowią dramatyzacje tekstów niedramatycznych. Jest to dramat dokumentalny (przygotowany przez Ivana Trojana, Ljubo Puzina i Vjekoslava Jankovicia na podstawie wspomnień świadków powodzi) Poplava (Powódź), udramatyzowane (przez I. Trojana, autora scenariuszy) i wystawione w szkołach Cvelferii opowiadania Mary Švel Gamiršek z tomu Priča za Sveu i Karen (Opowieść dla Svei i Karen) oraz dramatyzacja noweli Josipa Kozarca Tena (Tena), którą przygotowała (napisała scenariusz) Marija Pekaić-Mikuljan. Na tych trzech osobowościach twórczych (Švel Gamiršek, Kozarac i Peakić-Mikuljan) oraz dramacie dokumentalnym koncentruje się wprowadzające studium historycznoliterackie - doskonale osadzone w literaturze przedmiotu i wprawnie wskazujące zarówno elementy łączące dzieła $\mathrm{z}$ regionem, jak i przynależność do aktualnych nurtów rozwoju literatury chorwackiej.

Wszystkie tomy spaja strona graficzna - ilustracjami są kadry z filmu grupy SKIG. Wykonane pod wodą fotografie nadają monografiom intermedialny rys. Tomy 2-4 mają ponadto taką samą kompozycję: antologię poprzedza Uvodnik i Studija, wprawdzie brak pod nimi podpisów, jednak nietrudno się domyślić, że autorem „uvodników” (wstępów) we wszystkich książkach jest Goran Rem. Noszą charakter eseistyczny, stanowią raczej rekonstrukcję okoliczności towarzyszących przedsięwzięciu oraz rodzaj podziękowań dla osób, które przyczyniły się do realizacji projektu, niż pracę naukową podporządkowaną pewnej dyscyplinie narracyjnej.

Poza ocaleniem od zapomnienia, ważnym celem projektu była afirmacja, upomnienie się o uwagę i namysł nad bogactwem literackim (mnogość autorów i gatunków) oferowanym przez region obejmujący tylko dziewięć wsi, region, który obecnie zamieszkuje zaledwie dziesięć tysięcy mieszkańców. Pierwsze tego typu przedsięwzięcie w Chorwacji zaowocowało zebraniem i opublikowaniem całego dorobku (w jego kontinuum) pewnej przestrzennej i kulturowej 
odrębności. Summa Cvelferija - jeżeli dotrze do mieszkańców, a ambitnym celem zapowiadanym przez Gorana Rema było podarowanie publikacji każdej z tysiąca dziewiętnastu cvelferskich rodzin) - powinna przyczynić się do wzrostu świadomości identyfikacyjnej wśród samych mieszkańców Cvelferii oraz do uświadomienia ponadregionalnemu/narodowemu odbiorcy unikatowego charakteru regionalnych tradycji i konieczności otoczenia szczególną troską zarówno regionu, jak i jego dziedzictwa.

Autorzy pionierskich chrestomatii - słusznie - wychodzą z założenia, że poznanie narodowego całokształtu, różnorodności i niepowtarzalności możliwe jest poprzez zbadanie tradycji i współczesności regionów. Nie ulega wątpliwości, że synekdochiczny obraz narodowej literatury rysuje się imponująco, a pięciotomowa Cvelferica stanowi fantastyczny zbiór źródeł do badań regionalnych, kroatystycznych, komparatystycznych (wewnątrzchorwackich oraz glokalnych), kulturologicznych i etnograficznych.

\section{BIBLIOGRAFIA}

Brešić, V. (2004). Slavonska književnost i novi regionalizam. Osijek: Knjižnica Neotradicija.

Grgić, D. (2015). Priroda koja napada i kultura koja pismom brani. W: Cvelferica, panonizam, pismo književnosti, znanosti i kulture: Projekt (ss. 15-16). Osijek: Udruga duhovno hrašće, Društvo hrvatskih književnika, Organak slavonsko-baranjsko-srijemski.

Jukić, S., \& Rem, G. (2015a). Cvelferica, ispod sto jata vrana i između sto njiva: Poezija i metapismo. Osijek: Udruga duhovno hrašće, Društvo hrvatskih književnika, Organak slavonsko-baranjsko-srijemski.

Jukić, S., \& Rem, G. (2015b). Cvelferica, ili jedan je Cvelfer tjedan-dva ranije sanjao: Proza. Osijek: Udruga duhovno hrašće, Društvo hrvatskih književnika, Organak slavonsko-baranjsko-srijemski.

Jukić, S., Pšihistal, R., Rem, G., \& Trojan, I. (2015). Cvelferica, panonizam, pismo književnosti, znanosti i kulture: Projekt. Osijek: Udruga duhovno hrašæe, Društvo hrvatskih književnika, Organak slavonsko-baranjsko-srijemski.

Marijanović, S. (Red.). (1996). Književni Osijek. Osijek: Pedagoški fakultet.

Muhoberac, M. (1997). Skice za Mediteran: Svjetlosna mizanscena Novakove proze. Dubrov$n i k,(8), 129-138$.

Nagulov, F. (2016). Bol koja seže u beskraj. Vijenac, (594). Pobrano 27 grudnia 2016, z www. matica.hr/vijenac/594/Bol\%20koja\%20seže\%20u\%20beskraj

Pavličić, P. (1995). Južno od sjevera, sjeverno od juga. Dubrovnik, (6), 15-19. 
Pšihistal, R., \& Rem, G. (2009). Vinkovačka književna povjesnica. Vinkovci: Ogranak Matice hrvatske u Vinkovcima.

Pšihistal, R., \& Rem, G. (2016). Cvelferica, žena se opremi u bilo, stavi žari i ajd: Tradicijsko pismo. Osijek: Udruga duhovno hrašće, Društvo hrvatskih književnika, Organak slavonsko-baranjsko-srijemski.

Rem, G. (1997). Slavonsko ratno pismo. Osijek-Slavonski Brod-Vinkovci: Knjižnica Neotradicija.

Rem, G., \& Jukić, S. (2014a). Panonizam hrvatskoga pjesništva I: Studij Slava Panonije. Budimpešta-Osijek: Filozofski fakultet Univerziteta Eötvösa Loránda u Budimpešti, Ogranak DHK Slavonsko-baranjsko-srijemski, Filozofski Fakultet u Osijeku.

Rem, G., \& Jukić, S. (2014b). Panonizam hrvatskoga pjesništva II: Od Janusa Pannoniusa do Satana Panonskog: Interpretacije poetskih tekstova. Budimpešta-Osijek: Filozofski fakultet Univerziteta Eötvösa Loránda u Budimpešti, Ogranak DHK Slavonsko-baranjsko-srijemski, Filozofski Fakultet u Osijeku.

Rem, G., \& Trojan, I. (2015). Cvelferica, ili su to trnci kakve samo neizvjesnost $i$ iščekivanje mogu proizvesti: drama. Osijek: Udruga duhovno hrašće, Društvo hrvatskih književnika, Organak slavonsko-baranjsko-srijemski.

Sablić Tomić, H., \& Rem, G. (2001). Osječka čitanka. Sretne ulice. Osijek: Matica hrvatska.

Sablić Tomić, H., \& Rem, G. (2003). Slavonski tekst hrvatske književnosti. Zagreb: Matica hrvatska. Slamig, I. (1995). Hrvatski narod u spletu Mediterana. Dubrovnik, (6), 7-10.

Sorel, S. (2003). Mediteranizam tijela. Zagreb: Altagama.

Studija o panonizmu Sanje Jukić i Gorana Rema: Cvelferica: u šestoknjižnome čudu uskrsnuo i Satan Panonski. (2016, czerwiec 16). Glas Slavonije. Pobrano 27 grudnia 2016, z http:// www.glas-slavonije.hr/304124/11/Cvelferica-U-sestoknjiznome-cudu-uskrsnuo-i-Satan -Panonski

\section{Synekdocha literatury chorwackiej}

Recenzja pięciotomowego dzieła, na które składają się poprzedzone krytycznymi omówieniami antologie tekstów: Cvelferica, panonizam, pismo književnosti, znanosti i kulture (Cvelferica, panonizm, tekst literatury, nauki i kultury), tomy 1-5, Društvo hrvatskih književnika, Cvelferija-Osijek 2015.

Słowa kluczowe: recenzja, antologia tekstów, panonizm, Osijek, Ivan Rogić 


\section{A Synecdoche of Croatian Literature}

A review of the five-volume work comprising an anthology of texts along with critical commentaries: Cvelferica, panonizam, pismo književnosti, znanosti i kulture (Cvelferica, Panonism, text of literature, education, and culture), volumes 1-5, Društvo hrvatskih književnika, Cvelferija-Osijek 2015.

Keywords: review, antology of texts, panonism, Osijek, Ivan Rogić

\section{Notka o autorze}

Krystyna Pieniążek-Marković (krypien@amu.edu.pl) - slawistka, kroatystka, polonistka, historyk literatury i kultury, profesor nadzwyczajny w Instytucie Filologii Słowiańskiej Uniwersytetu im. Adama Mickiewicza w Poznaniu. Autorka książek: Twórczość poetycka Antuna Branka Šimicia (Ze studiów nad poezją chorwackiego ekspresjonizmu) (2000; wyd. chorwackie: Pjesničko stvaralaštvo Antuna Branka Šimića, 2000), „Ja”-człowiek i świat w najnowszej poezji chorwackiej (1990-2010) (2011). Zainteresowania naukowe: literatura i kultura chorwacka od romantyzmu po współczesność (ze szczególnym uwzględnieniem okresu przełomów); chorwacki dyskurs pamięciowy i tożsamościowy w testach podróży i narracjach kulinarnych.

Krystyna Pieniążek-Marković, PhD (krypien@amu.edu.pl) - expert in Slavic, Croatian, and Polish studies, historian of literature and culture, Associate Professor at the Institute of Slavic Philology, Adam Mickiewicz University in Poznań. Authoress of the books: Twórczość poetycka Antuna Branka Šimicia (Ze studiów nad poezja chorwackiego ekspresjonizmu) (2000; Croatian edition: Pjesničko stvaralaštvo Antuna Branka Šimića, 2000), „Ja”-człowiek $i$ świat w najnowszej poezji chorwackiej (1990-2010) (2011). Research interests: Croatian literature and culture from the Romanticism until the present (including the time of the periodical turns), Croatian memory and identity discourse in travel texts and culinary narratives. 